\title{
Dengue research: a bibliometric analysis of worldwide and Arab publications during 1872-2015
}

Sa'ed H. Zyoud ${ }^{1,2}$

\begin{abstract}
Background: Dengue is an important emerging and re-emerging arboviral infection globally as a rapidly growing and widespread public health problem, with transmission occurring in more than 128 countries in Asia, Americas, southeast Africa, western Pacific, and eastern Mediterranean regions. Therefore, the aim of this study was to characterize and quantify the scientific output of dengue research in Arab countries relative to that worldwide by using a bibliometric analysis.
\end{abstract}

Methods: The standardized search approach based on the use of the the keyword "dengue" in the title, abstract, and keyword field was used to get research output related to dengue at a global level. All data related to dengue were collected from the past to December 31, 2015.

Results: A total of 19,581 dengue-related documents identified in the Scopus database. The results show that the study of dengue exhibits an overall upward trend from 1872 to 2015 with peak publications in 2014. The leading countries in dengue research were the USA (4,709; $24.05 \%)$, India (1,942; $9.92 \%)$, Brazil (1,530; $7.81 \%)$, Thailand $(1,260 ; 6.43 \%)$, the UK $(1,129 ; 5.77 \%)$, and France $(1,087 ; 5.55 \%)$. Only 226 (1.16 \% of the overall global research effort in the dengue field) articles were published from the Arab region. The total number of citations for all publications was 352,710, with an average of 18.0 citations per publication. Furthermore, the $h$-index for all extracted data related to dengue research was 186. Kingdom of Saudi Arabia (KSA) was the most productive country in Arab region with 102 documents representing $45.1 \%$. Furthermore, the $h$-index for all extracted data related to dengue research was 27 . The USA was Arab's most main cooperative partner (46, 20.4\%), followed by India (36, $15.9 \%$ ).

Conclusions: The amount of literature related to dengue research has considerably increased over the last decade. This bibliometric analysis has demonstrated the leading role that the USA, India, Brazil, Thailand, the UK, and France play in dengue research. The Arab world produced fewer publications related to dengue with lower quality than other world countries.

Keywords: Dengue, Bibliometric, Scopus, Arab world, Citations

\section{Background}

Dengue is an important emerging and re-emerging arboviral infection globally as a rapidly growing and widespread public health problem, with transmission occurring in more than 128 countries in Asia, Americas, southeast Africa, western Pacific, and eastern Mediterranean regions $[1,2]$. It is estimated that each year, around 390 million

\footnotetext{
Correspondence: saedzyoud@yahoo.com; saedzyoud@najah.edu

${ }^{1}$ Poison Control and Drug Information Center (PCDIC), College of Medicine and Health Sciences, An-Najah National University, Nablus 44839, Palestine ${ }^{2}$ Department of Clinical and Community Pharmacy, College of Medicine and Health Sciences, An-Najah National University, Nablus 44839, Palestine
}

people are infected with dengue, of which 96 million develop any level of disease severity [3], leading to approximately 21,000 deaths [3, 4]. The clinical spectrum of dengue infection can vary from asymptomatic to severe manifestations of haemorrhagic fever, hypovolaemic shock, and organ impairment $[1,5]$. However, some cases are often accompanied with symptoms such as sore throat, arthralgia, febrile illness anorexia, headaches, myalgia, and a macular skin rash [6-8].

Dengue outbreaks worldwide have progressively increased [9-14], with recent outbreaks in the North 
Africa and Middle East regions [1, 15, 16]. In recent years, bibliometric analysis has been widely conducted to evaluate scientific research activities in many fields of infectious diseases such as chikungunya [17], Ebola virus disease [18, 19], influenza [20], John Cunningham virus [21], leishmaniasis [22, 23], Mayaro virus fever [24], Malaria [25], yellow fever disease [26], and Zika virus [27]. Bibliometrics is a statistical analysis of written publications and is used to provide quantitative and qualitative analysis of available data deposited at major multidisciplinary journal-indexing database such as Scopus.

Many research fields use bibliometric analysis to assess the scientific research patterns of publication year, document type, countries, journal, impact factors (IF), institution, number of citations, $h$-index, and international collaboration in global trends studies of specific fields [28-34]. It is thought that health research productivity from Arab region is still lagging far behind compared to worldwide publishing production [35-37]. Although the research output in some world regions such as India, China, and Brazil has been evaluated for dengue research [38-40], no study has focused on the scientific output of dengue research in Arab countries relative to that worldwide. Therefore, the aim of this study was to characterize and quantify the scientific output of dengue research in Arab countries relative to that worldwide by using a bibliometric analysis.

\section{Methods}

\section{Study design}

This study used a bibliometric analysis based in previous studies [28, 30, 32-34, 41].

\section{Data source}

This bibliometric study was built on April 2, 2016 based on the online version of Scopus database, which was developed by Elsevier. Note that there are several other databases that could be used in the bibliometric analysis including Web of Science, Google Scholar, and PubMed. However, this study only focuses on the data of Scopus which are assumed to be of the largest database $[42,43]$.

\section{Search strategy}

For bibliometric analysis, the standardized search approach based on the use of the the keyword "dengue" in the title, abstract, and keyword field was used to get research output related to dengue at a global level. All data related to dengue were collected from the past to December 31, 2015. For further analysis, data retrieved from Scopus were limited to Arab countries, including 22 countries (The Kingdom of Saudi Arabia (KSA), Tunisia, Egypt, Morocco, Algeria, Oman, Iraq, Jordan, United Arab Emirates, Syrian Arab Republic, Lebanon, Qatar, Palestine, Libyan Arab
Jamahiriya, Kuwait, Bahrain, Sudan, Yemen, Mauritania, Somalia, Djibouti, and Comoros). The analysed bibliometric indicators included publication year, document type, language of publications, publication distribution by countries/ territories, journal, impact factors (IF), institution, number of citations, $h$-index, and international collaboration. As the 2016 data did not represent a complete year, such data were excluded from the analysis. Furthermore, items coded as errata were excluded from further analysis.

\section{Ethical issues}

As there were no humans involved in this study, research using existing data from secondary sources is considered it to be exempt from the institutional review board (IRB) approval process.

\section{Data analysis}

Data downloaded from Scopus were and organized into Microsoft Excel 2007 and then be used for further analysis to get the ten top-ranked for most bibliometric indicators and they were appeared in descending order from 1 to 10 using the standard competition ranking (SCR); (1-2-2-4 rule). Descriptive statistics were used to determine the frequency, percentage, sum, and average. The $h$-index and IF had been used to assess the quality and quantity of research output. The $h$-index was introduced in bibliometric analysis by Hirsch [44] to illustrate the scientific output of a country, organization, researcher, etc. Therefore, the $h$-index covers both the quantity (number of publications) and the impact (number of citations) [45-47]. The impact factor for journals was obtained from the Journal Citation Reports (JCR) ( Ranking: 2014 [48].

\section{Results}

There were a total of 19,581 dengue-related documents identified in the Scopus database that were published between 1872 and 2015. These documents were published from the across 12 document types. There were 14,434 paper articles comprising $73.71 \%$ of the total production, followed by reviews (10.26\%), and letters (4.31\%). Other document types such as editorial materials, proceedings papers, notes, and book reviews covered approximately $11.73 \%$ of the published literature. The total publications per year are demonstrated in Fig. 1. The results at global level show that the study of dengue exhibits an overall upward trend from 1872 to 2015 with peak publications in 2014 (data in 2015 may be incomplete as the databases lag, thus, the number of research output in 2015 may be increasing). In the included years, the number of Scopus publications increased very slowly until 1990, and then the numbers of publications noticeably increased after 2000 . The publications identified were published in 34 languages. The 


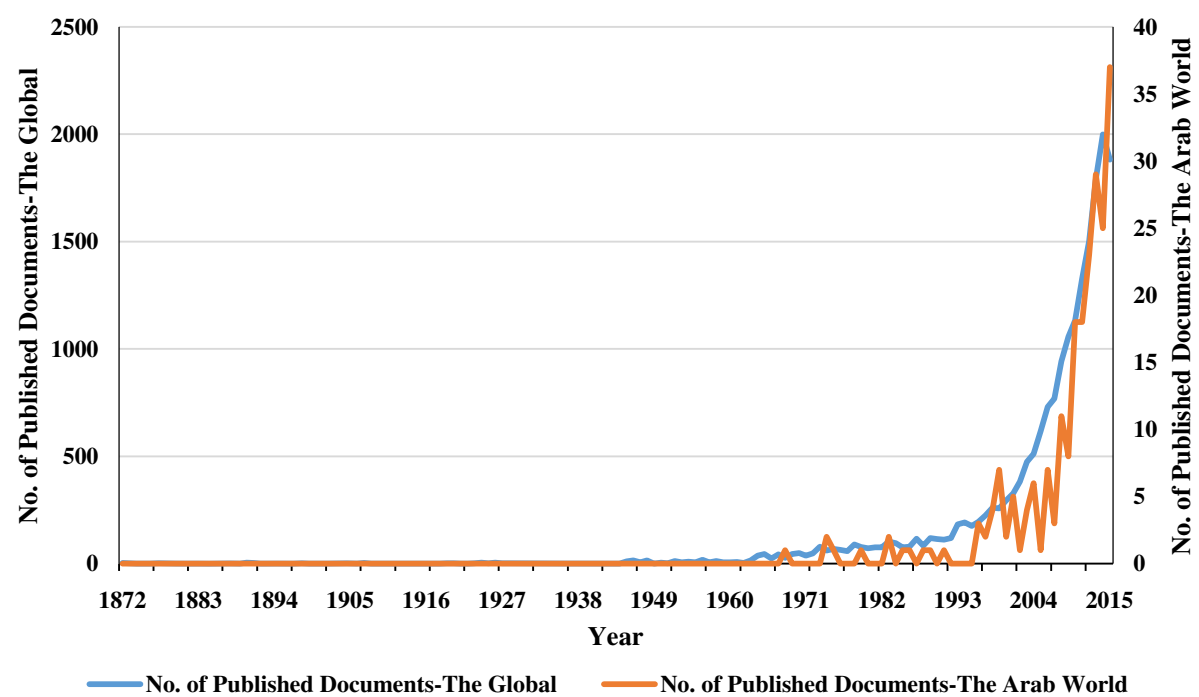

Fig. 1 Numbers of dengue research literature trends in Scopus between 1872 and 2015 at the global and Arab levels

most commonly used language were English (90.33\%), Spanish (3.57\%), and French (2.59\%).

Table 1 illustrates the top 10 countries in terms of absolute research production, their $h$-index and number of publication from international collaboration. The leading countries in dengue research were the USA $(4,709$; $24.05 \%)$, India (1,942; $9.92 \%)$, Brazil (1,530; $7.81 \%)$, Thailand $(1,260 ; 6.43 \%)$, the UK $(1,129 ; 5.77 \%)$, and France $(1,087 ; 5.55 \%)$. As expected, most publications related to dengue were carried out in North America, Europe, South Asia, and Latin America. This bibliometric analysis has demonstrated the leading role that the USA, India, Brazil, Thailand, the UK, and France play in dengue research (Table 1).

In case of number of publications with multinational researchers, France tops the list with 147 countries, followed by the USA with 146 countries, and the UK with 126 countries. Furthermore, the UK (71.12\%) had the highest percentage of documents in collaboration, followed by $56.03 \%$ for France, $52.54 \%$ for Thailand, and $52.11 \%$ for India from the total number of documents for each country. The total number of citations for all publications was 352,710 , with an average of 18.0 citations per publication. Furthermore, the $h$-index for all extracted data related to dengue research was 186 . The best $h$-index value is achieved by the USA (159) followed by the UK (92), Thailand (78), and France (76); (Table 1).

The Arab world produced fewer publications related to dengue. Only 226 (1.16 \% of the overall global research effort in the dengue field) articles were published from the Arab region across 7 document types.

Table 1 Top 10 most prolific countries of publications related to dengue in the world during 1872-2015 $(n=19,581)$

\begin{tabular}{|c|c|c|c|c|c|}
\hline$\overline{S C R}$ & Countries & Articles (\%) & $h$-index & $\begin{array}{l}\text { Collaborations with } \\
\text { foreign countries }\end{array}$ & $\begin{array}{l}\text { Number }(\%)^{a} \text { of publications } \\
\text { with international authors }\end{array}$ \\
\hline $1^{\text {st }}$ & United States & $4,709(24.05)$ & 159 & 146 & $2,030(43.11)$ \\
\hline $2^{\text {nd }}$ & India & $1,942(9.92)$ & 52 & 106 & $1,012(52.11)$ \\
\hline $3^{\text {rd }}$ & Brazil & $1,530(7.81)$ & 60 & 113 & 440 (28.76) \\
\hline $4^{\text {th }}$ & Thailand & $1,260(6.43)$ & 78 & 69 & $662(52.54)$ \\
\hline $5^{\text {th }}$ & United Kingdom & $1,129(5.77)$ & 92 & 126 & 803 (71.12) \\
\hline $6^{\text {th }}$ & France & $1,087(5.55)$ & 76 & 147 & 609 (56.03) \\
\hline $7^{\text {th }}$ & Australia & $783(4.00)$ & 68 & 100 & 393 (50.19) \\
\hline $8^{\text {th }}$ & Singapore & $774(3.95)$ & 59 & 104 & $372(48.06)$ \\
\hline $9^{\text {th }}$ & Malaysia & $628(3.21)$ & 39 & 108 & 209 (33.28) \\
\hline $10^{\mathrm{h}}$ & Japan & $618(3.16)$ & 48 & 53 & $289(46.76)$ \\
\hline
\end{tabular}

SCR Standard competition ranking

${ }^{\text {a }}$ ercentage of publications with international authors from the total number of publications for each country 
There were 187 paper articles comprising $82.7 \%$ of the total production, followed by reviews $(7.5 \%)$, and letters (3.1\%). Editorial materials, proceedings papers, notes, and book reviews covered approximately $6.7 \%$ of the published literature. The total publications per year are demonstrated in Fig. 1. The results from Arab world show that the study of dengue exhibits an overall upward trend from 1968 to 2015 with peak publications in 2015. Table 2 shows that KSA was the most productive country with 102 documents representing $45.1 \%$, followed by Egypt (58; $25.7 \%)$, Sudan (21; $9.3 \%$ ), and Kuwait $(21 ; 9.3 \%)$. No published data related to dengue were available from Comoros, and Mauritania. In Arab world, KSA and Egypt were at positions 34 and 46 respectively. The Arab countries have cooperated with 87 countries/ territories in the field of dengue research. The most internationally collaborative countries/ territories appears in Fig. 2. The total number of citations that got for publications $(n=133)$ from collaboration was 1,918 . The USA was Arab's most main cooperative partner $(46,20.4 \%)$, followed by India (36, $15.9 \%)$, France $(19,8.4 \%)$ and Malaysia (18, $8 \%$ ). The total number of citations for all publications was 2,683, with an average of 12 citations per publication. Furthermore, the $h$-index for all extracted data related to dengue research was 27. In addition, Egypt achieved the highest $h$-index (value of $h$-index $=15$ ).

The top 10 most productive journals based on the number of publication at global level were analyzed (Table 3). The 10 most prolific journals together produced 3,535 publications, comprising $18.05 \%$ of worldwide researchers' contributions during 1872-2015. The American Journal of Tropical Medicine and Hygiene published the most publications $(755,3.86 \%)$ by worldwide researchers, followed by the Plos Neglected Tropical Diseases, with 494 (2.52 \%), Southeast Asian Journal of Tropical Medicine and Public Health with 393 (2.01), and Plos One with 391 (2.00\%). Most journals in the list of the top ranking journals ( 9 journals out of 10) had IF. The IF for journals ranged from 0.719-6.751. Furthermore, the top 10 most productive journals based on the number of publication at Arab world level were analyzed (Table 4). The 10 most prolific journals together produced 67 papers, comprising $29.6 \%$ of Arab authors' contributions during 1968-2015. The Parasitology Research, and Dengue Bulletin published the most publications (9 publications for each journal, (4.0 \%)) by Arab authors, followed by the Eastern Mediterranean Health Journal,

Table 2 Bibliometric analysis of the 226 documents from the Arab world during 1968-2015

\begin{tabular}{|c|c|c|c|c|}
\hline$\overline{S C R^{a}}$ & Countries & $\begin{array}{l}\text { Total number of articles } \\
\text { for the whole period (\%) }\end{array}$ & $h$-index & $\begin{array}{l}\text { Number of documents } \\
\text { with international collaboration }\end{array}$ \\
\hline $1^{\text {st }}$ & KSA & $102(45.1)$ & 11 & 68 \\
\hline $2^{\text {nd }}$ & Egypt & $58(25.7)$ & 15 & 49 \\
\hline $3^{\text {rd }}$ & Sudan & $21(9.3)$ & 8 & 11 \\
\hline $3^{\text {rd }}$ & Kuwait & $21(9.3)$ & 11 & 14 \\
\hline $5^{\text {th }}$ & Tunisia & $14(6.2)$ & 7 & 11 \\
\hline $6^{\text {th }}$ & UAE & $10(4.4)$ & 6 & 8 \\
\hline $6^{\text {th }}$ & Oman & $10(4.4)$ & 3 & 5 \\
\hline $8^{\text {th }}$ & Yemen & $7(3.1)$ & 5 & 7 \\
\hline $8^{\text {th }}$ & Morocco & $7(3.1)$ & 5 & 3 \\
\hline $10^{\text {th }}$ & Qatar & $6(2.7)$ & 2 & 6 \\
\hline $11^{\text {th }}$ & Jordan & $5(2.2)$ & 5 & 4 \\
\hline $11^{\text {th }}$ & Bahrain & $5(2.2)$ & 2 & 4 \\
\hline $13^{\text {th }}$ & Algeria & $4(1.8)$ & 2 & 3 \\
\hline $13^{\text {th }}$ & Lebanon & $4(1.8)$ & 3 & 3 \\
\hline $15^{\text {th }}$ & Palestine & $3(1.3)$ & 3 & 3 \\
\hline $16^{\text {th }}$ & Iraq & $2(0.9)$ & 2 & 2 \\
\hline $16^{\text {th }}$ & Somalia & $2(0.9)$ & 2 & 2 \\
\hline $16^{\text {th }}$ & SAR & $2(0.9)$ & 2 & 2 \\
\hline $16^{\text {th }}$ & Djibouti & $2(0.9)$ & 1 & 1 \\
\hline $20^{\text {th }}$ & LAJ & $1(0.4)$ & 1 & 1 \\
\hline
\end{tabular}

SCR Standard competition ranking, KSA Kingdom of Saudi Arabia, UAE United Arab Emirates, SAR Syrian Arab Republic, LAJ Libyan Arab Jamahiriya ${ }^{a}$ Equal countries have the same ranking number, and then a gap is left in the ranking numbers 


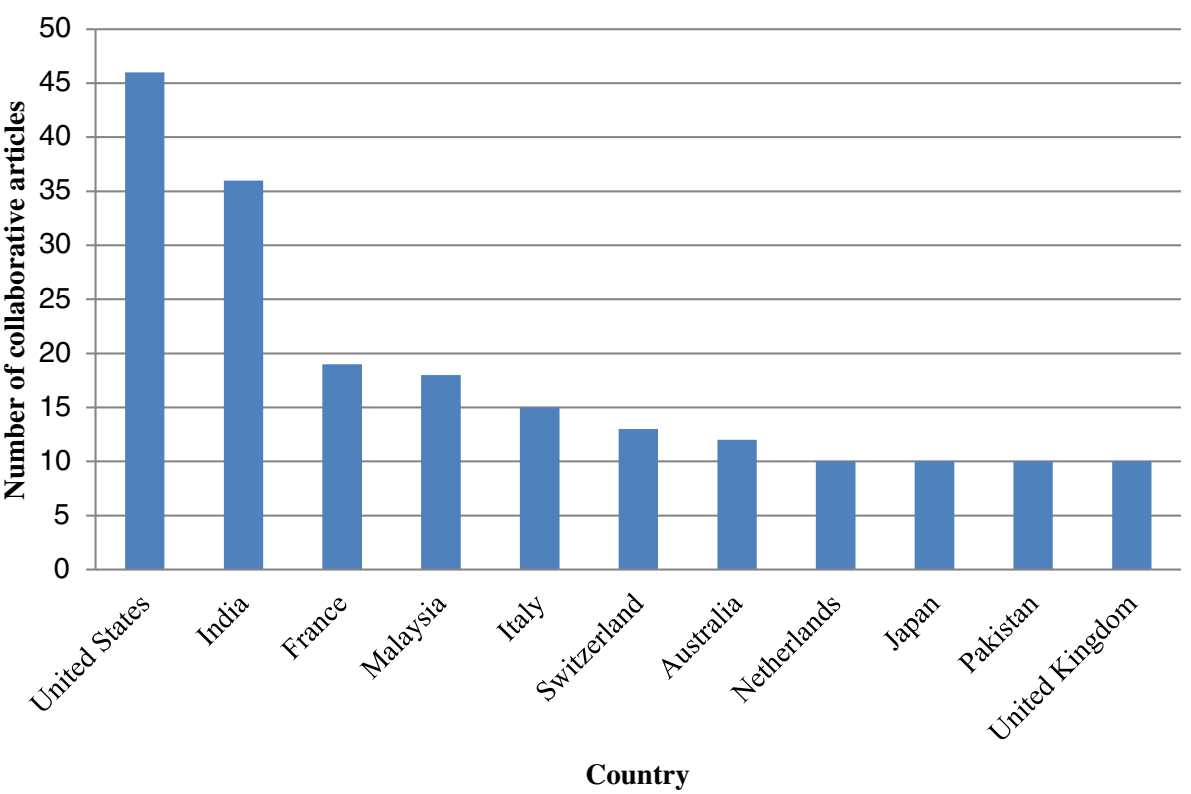

Fig. 2 The most 11 internationally collaborative countries/territories with Arab world

with 7 (3.1\%). Most journals in the list of the top ranking journals ( 7 journals out of 11) had IF. The IF for journals ranged from 1.839 to 3.247 .

At global level, the number of citations ranged from 1451 for the top cited article to 645 for the $10^{\text {th }}$. The most frequently cited article was published in 1998 in Clinical Microbiology Reviews (IF $=17.406)$ by Gubler [49], and cited 1451 times in Scopus database. The other 9 publications that were the most frequently cited in the field of dengue research at global level are shown in

Table 3 The 10 most published journals worldwide during $1968-2015(n=19,581)$

\begin{tabular}{|c|c|c|c|}
\hline SCR & Journal & Frequency (\%) & $\mathrm{IF}^{\mathrm{a}}$ \\
\hline $1^{\text {st }}$ & $\begin{array}{l}\text { American Journal of Tropical } \\
\text { Medicine and Hygiene }\end{array}$ & $755(3.86)$ & 2.699 \\
\hline $1^{\text {st }}$ & Plos Neglected Tropical Diseases & $494(2.52)$ & 4.446 \\
\hline $3^{\text {rd }}$ & $\begin{array}{l}\text { Southeast Asian Journal of } \\
\text { Tropical Medicine and } \\
\text { Public Health }\end{array}$ & $393(2.01)$ & 0.719 \\
\hline $4^{\text {th }}$ & Plos One & $391(2.00)$ & 3.234 \\
\hline $5^{\text {th }}$ & Journal of Virology & $380(1.94)$ & 4.439 \\
\hline $6^{\text {th }}$ & Dengue Bulletin & $254(1.30)$ & NA \\
\hline $7^{\text {th }}$ & Virology & $229(1.17)$ & 3.321 \\
\hline $8^{\text {th }}$ & Emerging Infectious Diseases & $223(1.14)$ & 6.751 \\
\hline $9^{\text {th }}$ & $\begin{array}{l}\text { Transactions of the Royal } \\
\text { Society of Tropical Medicine } \\
\text { and Hygiene }\end{array}$ & $212(1.08)$ & 1.839 \\
\hline $10^{\text {th }}$ & Vaccine & $204(1.04)$ & 3.624 \\
\hline
\end{tabular}

SCR Standard competition ranking, NA Not available, IF Impact factor

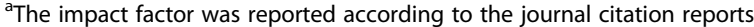
(JCR) 2014
Table 5 [3, 49-57]. At Arab level, the number of citations ranged from 162 for the top cited article to 59 for the $10^{\text {th }}$. The most frequently cited article was published in 2006 in Transactions of the Royal Society of Tropical Medicine and Hygiene (IF $=1.839,2014$ ) by Boutayeb [58], and cited 162 times in Scopus database. The other 9 publications that were the most frequently cited in the

Table 4 The 10 most published journals from the Arab world during 1968-2015 $(n=226)$

\begin{tabular}{|c|c|c|c|}
\hline $\mathrm{SCR}^{\mathrm{a}}$ & Journal & $\begin{array}{l}\text { Frequency } \\
(\%)\end{array}$ & $\mathrm{IF}^{\mathrm{b}}$ \\
\hline $1^{\text {st }}$ & Parasitology Research & $9(4.0)$ & 2.098 \\
\hline $1^{\text {st }}$ & Dengue Bulletin & $9(4.0)$ & NA \\
\hline $3^{\text {rd }}$ & Eastern Mediterranean Health Journal & $7(3.1)$ & NA \\
\hline $4^{\text {th }}$ & Journal of Infection and Public Health & $6(2.7)$ & NA \\
\hline $4^{\text {th }}$ & Biosciences Biotechnology Research Asia & $6(2.7)$ & NA \\
\hline $4^{\text {th }}$ & $\begin{array}{l}\text { American Journal of Tropical Medicine } \\
\text { and Hygiene }\end{array}$ & $6(2.7)$ & 2.699 \\
\hline $4^{\text {th }}$ & $\begin{array}{l}\text { Transactions of the Royal Society of Tropical } \\
\text { Medicine and Hygiene }\end{array}$ & $6(2.7)$ & 1.839 \\
\hline $8^{\text {th }}$ & Journal of Medical Virology & $5(2.2)$ & 2.347 \\
\hline $8^{\text {th }}$ & BMC Infectious Diseases & $5(2.2)$ & 2.613 \\
\hline $10^{\text {th }}$ & Plos One & $4(1.8)$ & 3.234 \\
\hline $10^{\text {th }}$ & $\begin{array}{l}\text { FEMS Immunology and Medical } \\
\text { Microbiology }\end{array}$ & $4(1.8)$ & 3.078 \\
\hline
\end{tabular}

SCR Standard competition ranking, NA Not available, IF Impact factor ${ }^{a}$ Equal journals have the same ranking number, and then a gap is left in the ranking numbers

${ }^{\text {b}}$ The impact factor was reported according to the journal citation reports (JCR) 2014 
Table 5 Top 10 most cited articles in Scopus related to dengue worldwide

\begin{tabular}{|c|c|c|c|c|c|}
\hline SCR & Authors & Title & $\begin{array}{l}\text { Year of } \\
\text { publication }\end{array}$ & Source title & $\begin{array}{l}\text { Cited } \\
\text { by }\end{array}$ \\
\hline $1^{\text {st }}$ & Gubler [49] & Dengue and dengue hemorrhagic fever & 1998 & $\begin{array}{l}\text { Clinical Microbiology } \\
\text { Reviews }\end{array}$ & 1451 \\
\hline $2^{\text {nd }}$ & Bhatt et al. [3] & The global distribution and burden of dengue & 2013 & Nature & 991 \\
\hline $3^{\text {rd }}$ & Halstead [50] & Pathogenesis of dengue: Challenges to molecular biology & 1988 & Science & 991 \\
\hline $4^{\text {th }}$ & Lanciotti et al. [51] & $\begin{array}{l}\text { Rapid detection and typing of dengue viruses from clinical } \\
\text { samples by using reverse transcriptase-polymerase chain reaction }\end{array}$ & 1992 & $\begin{array}{l}\text { Journal of Clinical } \\
\text { Microbiology }\end{array}$ & 896 \\
\hline $5^{\text {th }}$ & Vaughn et al. [52] & $\begin{array}{l}\text { Dengue viremia titer, antibody response pattern, and virus } \\
\text { serotype correlate with disease severity }\end{array}$ & 2000 & $\begin{array}{l}\text { Journal of Infectious } \\
\text { Diseases }\end{array}$ & 807 \\
\hline $6^{\text {th }}$ & Gubler [53] & $\begin{array}{l}\text { Epidemic dengue/dengue hemorrhagic fever as a public health, } \\
\text { social and economic problem in the } 21 \text { st century }\end{array}$ & 2002 & Trends in Microbiology & 749 \\
\hline $7^{\text {th }}$ & Halstead [54] & Dengue & 2007 & Lancet & 720 \\
\hline $8^{\text {th }}$ & $\begin{array}{l}\text { Guzmán and Kourí } \\
\text { [55] }\end{array}$ & Dengue: An update & 2002 & Lancet Infectious Diseases & 718 \\
\hline $9^{\text {th }}$ & Kuhn et al. [56] & $\begin{array}{l}\text { Structure of dengue virus: Implications for flavivirus organization, } \\
\text { maturation, and fusion }\end{array}$ & 2002 & Cell & 682 \\
\hline $10^{\text {th }}$ & Mackenzie et al. [57] & $\begin{array}{l}\text { Emerging flaviviruses: The spread and resurgence of Japanese } \\
\text { encephalitis, West Nile and dengue viruses }\end{array}$ & 2004 & Nature Medicine & 645 \\
\hline
\end{tabular}

SCR Standard competition ranking

field of dengue research at Arab level are shown in Table 6 [59-67].

Table 7 provides a list of the top 10 most productive institutes at global level between 1872 and 2015. Mahidol University in Thailand ranked first in the number of publications (620, 3.17 \%), followed by Fundacao Oswaldo Cruz in Brazil (495, $2.53 \%$ ), and Centers for Disease Control and Prevention in the USA (395, $2.02 \%)$. At Arab level, the top 10 most productive institutions for total publications are shown in Table 8. King Abdulaziz University in KSA ranked first in the number of publications (32, $14.2 \%)$, followed by U.S. Naval Medical Research Unit

Table 6 Top 10 most cited articles in Scopus related to dengue from Arab world

\begin{tabular}{|c|c|c|c|c|c|}
\hline$\overline{S C R^{a}}$ & Authors & Title & $\begin{array}{l}\text { Year of } \\
\text { publication }\end{array}$ & Source title & $\begin{array}{l}\text { Cited } \\
\text { by }\end{array}$ \\
\hline $1^{\text {st }}$ & Boutayeb [58] & $\begin{array}{l}\text { The double burden of communicable and } \\
\text { non-communicable diseases in developing countries }\end{array}$ & 2006 & $\begin{array}{l}\text { Transactions of the Royal Society of } \\
\text { Tropical Medicine and Hygiene }\end{array}$ & 162 \\
\hline $2^{\text {nd }}$ & $\begin{array}{l}\text { Chaturvedi et al. } \\
\text { [59] }\end{array}$ & $\begin{array}{l}\text { Cytokine cascade in dengue hemorrhagic fever: Implications } \\
\text { for pathogenesis }\end{array}$ & 2000 & $\begin{array}{l}\text { FEMS Immunology and Medical } \\
\text { Microbiology }\end{array}$ & 156 \\
\hline $3^{\text {rd }}$ & $\begin{array}{l}\text { Raghupathy et } \\
\text { al. [60] }\end{array}$ & Elevated levels of $\mathrm{IL}-8$ in dengue hemorrhagic fever & 1998 & Journal of Medical Virology & 108 \\
\hline $4^{\text {th }}$ & $\begin{array}{l}\text { Graham et al. } \\
{[61]}\end{array}$ & $\begin{array}{l}\text { A prospective seroepidemiologic study on dengue in children } \\
\text { four to nine years of age in Yogyakarta, Indonesia I. Studies } \\
\text { in 1995-1996 }\end{array}$ & 1999 & $\begin{array}{l}\text { American Journal of Tropical } \\
\text { Medicine and Hygiene }\end{array}$ & 104 \\
\hline $5^{\text {th }}$ & $\begin{array}{l}\text { Agarwal et al. } \\
{[62]}\end{array}$ & $\begin{array}{l}\text { A clinical study of the patients with dengue hemorrhagic fever } \\
\text { during the epidemic of } 1996 \text { at Lucknow, India }\end{array}$ & 1999 & $\begin{array}{l}\text { Southeast Asian Journal of } \\
\text { Tropical Medicine and Public } \\
\text { Health }\end{array}$ & 80 \\
\hline $6^{\text {th }}$ & $\begin{array}{l}\text { Moutailler et al. } \\
\text { [63] }\end{array}$ & $\begin{array}{l}\text { Potential vectors of rift valley fever virus in the Mediterranean } \\
\text { region }\end{array}$ & 2008 & $\begin{array}{l}\text { Vector-Borne and Zoonotic } \\
\text { Diseases }\end{array}$ & 70 \\
\hline $7^{\text {th }}$ & $\begin{array}{l}\text { Chaturvedi et al. } \\
\text { [64] }\end{array}$ & $\begin{array}{l}\text { Sequential production of cytokines by dengue virus-infected } \\
\text { human peripheral blood leukocyte cultures }\end{array}$ & 1999 & Journal of Medical Virology & 68 \\
\hline $7^{\text {th }}$ & $\begin{array}{l}\text { Mustafa et al. } \\
{[66]}\end{array}$ & $\begin{array}{l}\text { Elevated levels of interleukin-13 and IL-18 in patients with } \\
\text { dengue hemorrhagic fever }\end{array}$ & 2001 & $\begin{array}{l}\text { FEMS Immunology and } \\
\text { Medical Microbiology }\end{array}$ & 68 \\
\hline $9^{\text {th }}$ & $\begin{array}{l}\text { Abubakar et al. } \\
\text { [65] }\end{array}$ & $\begin{array}{l}\text { Global perspectives for prevention of infectious diseases } \\
\text { associated with mass gatherings }\end{array}$ & 2012 & The Lancet Infectious Diseases & 63 \\
\hline $10^{\text {th }}$ & Barniol et al. [67] & $\begin{array}{l}\text { Usefulness and applicability of the revised dengue case } \\
\text { classification by disease: Multi-centre study in } 18 \text { countries }\end{array}$ & 2011 & BMC Infectious Diseases & 59 \\
\hline
\end{tabular}


Table 7 The top 10 most productive institutes at global level

\begin{tabular}{lll}
\hline SCR & Institution, country & $\begin{array}{l}\text { No. of } \\
\text { documents (\%) }\end{array}$ \\
\hline $1^{\text {st }}$ & Mahidol University, Thailand & $620(3.17)$ \\
$2^{\text {nd }}$ & Fundacao Oswaldo Cruz, Brazil & $495(2.53)$ \\
$3^{\text {rd }}$ & $\begin{array}{l}\text { Centers for Disease Control and } \\
\text { Prevention, USA }\end{array}$ & $395(2.02)$ \\
$4^{\text {th }}$ & Instituto de Medicina Tropical Pedro Kouri, Cuba & $309(1.58)$ \\
$5^{\text {th }}$ & University of Malaya, Malaysia & $297(1.52)$ \\
$6^{\text {th }}$ & Institut Pasteur, Paris, France & $294(1.50)$ \\
$7^{\text {th }}$ & Universidade de Sao Paulo - USP, Brazil & $274(1.40)$ \\
$8^{\text {th }}$ & Walter Reed Army Institute of Research, USA & $255(1.30)$ \\
$9^{\text {th }}$ & Armed Forces Research Institute of Medical & $250(1.28)$ \\
& $\quad$ Sciences, Thailand & $230(1.17)$ \\
$10^{\text {th }}$ & University of Oxford, UK &
\end{tabular}

SCR Standard competition ranking

No. 3 in Egypt (17, 7.5 \%), Ministry of Health in KSA (17, $7.5 \%$ ), and Faculty of Medicine in Kuwait (17, $7.5 \%$ ).

\section{Discussion}

In this study, I employed a bibliometric approach to analyse the research trends of dengue at global level and in the Arab world. The publications on dengue presented a solid growth with an increasing number of articles. This bibliometric analysis has demonstrated the leading role that the USA, India, Brazil, Thailand, the UK, and France play in dengue research. USA was the leading country in research output on dengue. Although the number of dengue outbreaks in the USA there is less than in other countries [3], these findings are in line

Table 8 The top 10 most productive institutes from or collaborating with Arab world affiliations during the study period

\begin{tabular}{lll}
\hline SCR $^{\text {a }}$ & Institution, country & No. of documents (\%) \\
\hline $1^{\text {st }}$ & King Abdulaziz University, KSA & $32(14.2)$ \\
$2^{\text {nd }}$ & $\begin{array}{l}\text { U.S. Naval Medical Research Unit No. 3 } \\
\text { (NAMRU-3), Egypt }\end{array}$ & $17(7.5)$ \\
$2^{\text {nd }}$ & Ministry of Health, KSA & $17(7.5)$ \\
$2^{\text {nd }}$ & Faculty of Medicine, Kuwait & $17(7.5)$ \\
$5^{\text {th }}$ & Organisation Mondiale de la Sante, & $14(6.2)$ \\
& Switzerland & $10(4.4)$ \\
$6^{\text {th }}$ & Umm Al Qura University, KSA \\
$6^{\text {th }}$ & King George's Medical University, India & $10(4.4)$ \\
$6^{\text {th }}$ & Universita di Pisa, Italy & $10(4.4)$ \\
$9^{\text {th }}$ & King Saud University, KSA & $9(4.0)$ \\
$10^{\text {th }}$ & Bharathiar University, India & $8(3.5)$ \\
$10^{\text {th }}$ & Universita degli Studi di Roma & $8(3.5)$ \\
& La Sapienza, Italy
\end{tabular}

SCR Standard competition ranking, KSA Kingdom of Saudi Arabia ${ }^{a}$ Equal institutes have the same ranking number, and then a gap is left in the ranking numbers with those of previous studies, especially those in other infectious fields [17, 18, 23, 24]. Overall, Brazil, India, Thailand, Singapore, Malaysia, Japan, and Australia, accounted for most of the dengue research activity at global level. A possible explanation for these results may be due to high prevalence of dengue in these countries which faced many outbreaks [68-74]. Another possible explanation for these findings could be recognized to the number of researchers and development of scientific research system in these countries. However, only KSA and Egypt among Arab countries ranked among the first 50 countries in terms of worldwide contribution to research productivity in the dengue. Among the Arab countries, KSA and Egypt achieved the top rank. High national incomes and large populations and are the most probable reasons for this achievement. These results are consistent with data obtained from previous studies, especially those in medical fields [29, 31, 37, 75-81]. Publications from Arab world received lower citation rate than that from the world; because researchers from Arab world have published their work in scientific journals with slightly lower citation rates or without IF such as Dengue Bulletin, Eastern Mediterranean Health Journal, Journal of Infection and Public Health; and Biosciences Biotechnology Research Asia. These findings are in line with those of previous studies [75, 77, 78, 82].

The current study designed to recognize scientific collaborations between Arab countries and non-Arab countries. The USA was Arab's most main cooperative partner. These results match those observed in earlier studies in the field of ophthalmology [77], and in the field of substance use disorders [83]. In addition, country with highest collaboration with researchers in India in dengue research was USA [84]. The investigation of publication output recognized several successful cases of researcher collaboration between Arab countries and Western Europe (France and Italy) and the Asiatic region (i.e. India and Malaysia). At the global level, the USA got a leadership position in dengue research with the largest publication followed by India [85]. Dengue disease has no borders and prevention; eradication and control of this disease requires worldwide efforts. Health-care systems in the Arab region are low priority in national spending plans and are perceived as being non-productive [86, 87]. Arab region has been the source of most fatal infectious diseases (e.g. Middle East respiratory syndrome coronavirus, West Nile Virus, and leishmaniasis), and they should heavily participate and cooperate in research in order to combat them [75]. The Arab countries have cooperated with 87 countries in the field of dengue research.

The current study is the first to assess the quantity and quality of global research effort in the dengue field worldwide and from Arab world. The most important limitation 
lies in the fact that the Scopus database only was used to extract data related to dengue. Articles published in non Scopus-cited journals were not studied, but it is interesting to note that the Scopus has several advantages more than others, as it is the largest abstract and citation database of peer-reviewed literature [42, 43, 88].

\section{Conclusions}

Based on 19,581 dengue-related documents from Scopus, this bibliometric analysis provided an overview of research in dengue and recognized some noteworthy issues in this field during the search period. The amount of literature related to dengue research has considerably increased over the last decade. This bibliometric analysis has demonstrated the leading role that the USA, India, Brazil, Thailand, the UK, and France play in dengue research. The Arab world produced fewer publications related to dengue with lower quality than other world countries. The result shows that KSA plays a leading role in dengue research through the number of publications with international collaboration in Arab world. The USA was Arab's leading internationally collaborative country, followed by India, France and Malaysia. Multinational collaboration can help dengue research get more international attention. More research is required to recognize what societal and individual level factors were involved in raising such a remarkable increase in quantity of dengue research in the last decade. Arab researchers especially in countries who at risk with dengue disease need to take the lead and promote research projects in this field of infection as an important public health concern.

\section{Abbreviations}

IF: impact factor; IRB: institutional review board; JCR: Journal citation reports; KSA: Kingdom of Saudi Arabia; SCR: Standard competition ranking.

\section{Competing interests}

The author declares that he has no competing interests.

\section{Authors' contributions}

SZ conceptualized, designed the methodology, and implemented the study, and did the analysis and write-up. Then read, and approved the final manuscript.

\section{Funding sources}

No funding was received for writing this study.

Received: 16 March 2016 Accepted: 3 May 2016

Published online: 06 May 2016

\section{References}

1. Guzman MG, Harris E. Dengue. Lancet. 2015;385:453-65.

2. Wilder-Smith A, Byass P. The elusive global burden of dengue. Lancet Infect Dis. 2016. Article in press.

3. Bhatt $\mathrm{S}$, Gething PW, Brady OJ, Messina JP, Farlow AW, Moyes CL, Drake JM, Brownstein JS, Hoen AG, Sankoh O, et al. The global distribution and burden of dengue. Nature. 2013;496:504-7.

4. Fibriansah G, Lok SM. The development of therapeutic antibodies against dengue virus. Antiviral Res. 2016;128:7-19.

5. Jaenisch T, Tam DT, Kieu NT, Van Ngoc T, Nam NT, Van Kinh N, Yacoub S, Chanpheaktra N, Kumar V, See LL, et al. Clinical evaluation of dengue and identification of risk factors for severe disease: protocol for a multicentre study in 8 countries. BMC Infect Dis. 2016;16:120.

6. John TJ. Dengue fever and dengue haemorrhagic fever. Lancet. 2003;361:181-2.

7. Rigau-Pérez JG, Clark GG, Gubler DJ, Reiter P, Sanders EJ, Vorndam AV. Dengue and dengue haemorrhagic fever. Lancet. 1998;352:971-7.

8. Murray NE, Quam MB, Wilder-Smith A. Epidemiology of dengue: past, present and future prospects. Clin Epidemiol. 2013;5:299-309.

9. Gordon Smith CE. A localized outbreak of dengue fever in Kuala Lumpur: epidemiological and clinical aspects. Med J Malaya. 1956;10:289-303.

10. Johnston D, Viray M, Ushiroda J, Whelen AC, Sciulli R, Gose R, Lee R, Honda E, Park SY, Hawaii Dengue Response T. Notes from the field: outbreak of locally acquired cases of dengue fever - Hawaii, 2015. MMWR Morb Mortal Wkly Rep. 2016;65:34-5.

11. Khan J, Khan I, Amin I. A comprehensive entomological, serological and molecular study of 2013 dengue outbreak of swat, Khyber Pakhtunkhwa, Pakistan. PLoS One. 2016;11:e0147416.

12. Lin YP, Luo Y, Chen Y, Lamers MM, Zhou Q, Yang XH, Sanyal S, Mok CK, Liu ZM. Clinical and epidemiological features of the 2014 large-scale dengue outbreak in Guangzhou city, China. BMC Infect Dis. 2016;16:102.

13. Quam MB, Sessions O, Kamaraj US, Rocklov J, Wilder-Smith A. Dissecting Japan's dengue outbreak in 2014. Am J Trop Med Hyg. 2016;94:409-12.

14. Shen SQ, Wei HX, Fu YH, Zhang H, Mo QY, Wang XJ, Deng SQ, Zhao W, Liu $Y$, Feng XS. Multiple sources of infection and potential endemic characteristics of the large outbreak of dengue in Guangdong in 2014. Sci Rep. 2015;5:16913.

15. Al Awaidy ST, Al Obeidani I, Bawikar S, Al Mahrouqi S, Al Busaidy SS, Al Baqlani S, Patel PK. Dengue epidemiological trend in Oman: a 13-year national surveillance and strategic proposition of imported cases. Trop Doct. 2014:44:190-5.

16. Stanaway JD, Shepard DS, Undurraga EA, Halasa YA, Coffeng LE, Brady OJ, Hay SI, Bedi N, Bensenor IM, Castaneda-Orjuela CA, et al. The global burden of dengue: an analysis from the Global Burden of Disease Study 2013. Lancet Infect Dis. 2016. Article in Press.

17. Vera-Polania F, Munoz-Urbano M, Banol-Giraldo AM, Jimenez-Rincon M, Granados-Alvarez S, Rodriguez-Morales AJ. Bibliometric assessment of scientific production of literature on chikungunya. J Infect Public Health. 2015;8:386-8.

18. Cruz-Calderón S, Nasner-Posso KM, Alfaro-Toloza P, Paniz-Mondolfi AE, Rodriguez-Morales AJ. A bibliometric analysis of global Ebola research. Travel Med Infect Dis. 2015;13:202-4.

19. Zhao XY, Sheng L, Diao TX, Zhang Y, Wang L, Yanjun Z. Knowledge mapping analysis of Ebola research. Bratisl Lek Listy. 2015;116:729-34.

20. Fricke R, Uibel S, Klingelhoefer D, Groneberg DA. Influenza: a scientometric and density-equalizing analysis. BMC Infect Dis. 2013;13:454

21. Zheng HC, Yan L, Cui L, Guan YF, Takano Y. Mapping the history and current situation of research on John Cunningham virus - a bibliometric analysis. BMC Infect Dis. 2009:9:28.

22. Perilla-Gonzalez Y, Gomez-Suta D, Delgado-Osorio N, Hurtado-Hurtado N, Baquero-Rodriguez JD, Lopez-Isaza AF, Lagos-Grisales GJ, Villegas S, Rodriguez-Morales AJ. Study of the scientific production on leishmaniasis in Latin America. Recent Pat Antiinfect Drug Discov. 2014;9:216-22.

23. Ramos JM, Gonzalez-Alcaide G, Bolanos-Pizarro M. Bibliometric analysis of leishmaniasis research in Medline (1945-2010). Parasit Vectors. 2013;6:55.

24. Patiño-Barbosa A, Bedoya-Arias JE, Cardona-Ospina JA, Rodriquez-Morales AJ. Bibliometric assessment of the scientific production of literature regarding Mayaro. J Infect Public Health. 2015. Article in Press.

25. Munoz-Urbano M, Lopez-Isaza AF, Hurtado-Hurtado N, Gomez-Suta D, Murillo-Abadia J, Delgado-Osorio N, Lagos-Grisales GJ, Villegas S, MedinaMorales DA, Rodriguez-Morales AJ. Scientific research in malaria: bibliometric assessment of the Latin-American contributions. Recent Pat Antiinfect Drug Discov. 2014;9:209-15.

26. Bundschuh M, Groneberg DA, Klingelhoefer D, Gerber A. Yellow fever disease: density equalizing mapping and gender analysis of international research output. Parasit Vectors. 2013;6:331.

27. Martinez-Pulgarin DF, Acevedo-Mendoza WF, Cardona-Ospina JA, Rodriguez-Morales AJ, Paniz-Mondolfi AE. A bibliometric analysis of global zika research. Travel Med Infect Dis. 2016;14:55-7.

28. Zyoud SH. Bibliometric analysis on global Catha edulis (khat) research production during the period of 1952-2014. Glob Health. 2015;11:39.

29. Zyoud SH, Al-Jabi SW, Sweileh WM. Scientific publications from Arab world in leading journals of integrative and complementary medicine: a bibliometric analysis. BMC Complement Altern Med. 2015;15:308. 
30. Zyoud SH, Al-Jabi SW, Sweileh WM, Al-Khalil S, Alqub M, Awang R. Global methaemoglobinaemia research output (1940-2013): a bibliometric analysis. Springerplus. 2015:4:626.

31. Zyoud SH, Al-Jabi SW, Sweileh WM, Al-Khalil S, Zyoud SH, Sawalha AF, Awang R. The Arab world's contribution to solid waste literature: a bibliometric analysis. J Occup Med Toxicol. 2015;10:35.

32. Zyoud SH, Al-Jabi SW, Sweileh WM, Awang R, Waring WS. Global research productivity of $\mathrm{N}$-acetylcysteine use in paracetamol overdose: a bibliometric analysis (1976-2012). Hum Exp Toxicol. 2015;34:1006-16.

33. Zyoud SH, Al-Jabi SW, Sweileh WM, Awang R, Waring WS. Bibliometric profile of the global scientific research on methanol poisoning (1902-2012). J Occup Med Toxicol. 2015;10:17.

34. Zyoud SH, Al-Jabi SW, Sweileh WM, Waring WS. Scientific research related to calcium channel blockers poisoning: bibliometric analysis in Scopus, 1968-2012. Hum Exp Toxicol. 2015;34:1162-70.

35. El-Azami-El-Idrissi M, Lakhdar-Idrissi M, Ouldim K, Bono W, Amarti-Riffi A, Hida M, Nejjari C. Improving medical research in the Arab world. Lancet. 2013:382:2066-7.

36. Tadmouri GO, Bissar-Tadmouri N. Biomedical publications in an unstable region: the Arab world, 1988-2002. Lancet. 2003;362:1766.

37. Benamer HT, Bakoush O. Arab nations lagging behind other Middle Eastern countries in biomedical research: a comparative study. BMC Med Res Methodol. 2009;9:26.

38. Vera-Polania F, Perilla-Gonzalez Y, Martinez-Pulgarin DF, Baquero-Rodriguez JD, Munoz-Urbano M, Lagos-Gallego M, Lagos-Grisales GJ, Villegas S, Rodriguez-Morales AJ. Bibliometric assessment of the Latin-American contributions in dengue. Recent Pat Antiinfect Drug Discov. 2014;9:195-201.

39. Bhardwaj RK. Dengue fever: a bibliometric analysis of India's contributions to the research literature of this dangerous tropical disease. Sci Tech Libr. 2014;33:289-301

40. Vellaichamy A, Jeyshankar R. Dengue research in India and China: a comparative study using bibliometrics. Int J Lib Sci Inf Manag. 2015;1:1-9.

41. Zyoud SH, Al-Jabi SW, Sweileh WM. Worldwide research productivity of paracetamol (acetaminophen) poisoning: a bibliometric analysis (20032012). Hum Exp Toxicol. 2015;34:12-23.

42. Falagas ME, Pitsouni El, Malietzis GA, Pappas G. Comparison of PubMed, Scopus, Web of science, and Google scholar: strengths and weaknesses. FASEB J. 2008;22:338-42.

43. Kulkarni AV, Aziz B, Shams I, Busse JW. Comparisons of citations in Web of science, Scopus, and Google scholar for articles published in general medical journals. JAMA. 2009;302:1092-6.

44. Hirsch JE. An index to quantify an individual's scientific research output. Proc Natl Acad Sci U S A. 2005;102:16569-72.

45. Birks Y, Fairhurst C, Bloor K, Campbell M, Baird W, Torgerson D. Use of the h-index to measure the quality of the output of health services researchers. J Health Serv Res Policy. 2014;19:102-9.

46. Miroiu A. Axiomatizing the Hirsch index: quantity and quality disjoined. J Informetr. 2013;7:10-5.

47. Abdelrahman T, Brown J, Wheat J, Thomas C, Lewis W. Hirsch index value and variability related to general surgery in a UK deanery. J Surg Educ. 2016;73:111-5

48. Thomson Reuters. 2014 Journal Citation Reports ${ }^{\oplus} .2015$ [cited 2015 November 13]; Available from: http://www.isiknowledge.com.

49. Gubler DJ. Dengue and dengue hemorrhagic fever. Clin Microbiol Rev. 1998;11:480-96.

50. Halstead SB. Pathogenisis of dengue: challenges to molecular biology. Science. 1988;239:476-81.

51. Lanciotti RS, Calisher CH, Gubler DJ, Chang GJ, Vorndam AV. Rapid detection and typing of dengue viruses from clinical samples by using reverse transcriptase-polymerase chain reaction. J Clin Microbiol. 1992;30:545-51.

52. Vaughn DW, Green S, Kalayanarooj S, Innis BL, Nimmannitya S, Suntayakorn S, Endy TP, Raengsakulrach B, Rothman AL, Ennis FA, Nisalak A. Dengue viremia titer, antibody response pattern, and virus serotype correlate with disease severity. J Infect Dis. 2000;181:2-9.

53. Gubler DJ. Epidemic dengue/dengue hemorrhagic fever as a public health, socia and economic problem in the 21st century. Trends Microbiol. 2002;10:100-3.

54. Halstead SB. Dengue. Lancet. 2007:370:1644-52.

55. Guzmán MG, Kouri G. Dengue: an update. Lancet Infect Dis. 2002;2:33-42.

56. Kuhn RJ, Zhang W, Rossmann MG, Pletnev SV, Corver J, Lenches E, Jones CT, Mukhopadhyay S, Chipman PR, Strauss EG. Structure of dengue virus: implications for flavivirus organization, maturation, and fusion. Cell. 2002;108: 717-25.
57. Mackenzie JS, Gubler DJ, Petersen LR. Emerging flaviviruses: the spread and resurgence of Japanese encephalitis, West Nile and dengue viruses. Nat Med. 2004;10:598-109.

58. Boutayeb A. The double burden of communicable and non-communicable diseases in developing countries. Trans R Soc Trop Med Hyg. 2006;100:191-9.

59. Chaturvedi UC, Agarwal R, Elbishbishi EA, Mustafa AS. Cytokine cascade in dengue hemorrhagic fever: implications for pathogenesis. FEMS Immunol Med Microbiol. 2000;28:183-8.

60. Raghupathy R, Chaturvedi UC, Al-Sayer H, Elbishbishi EA, Agarwal R, Nagar R, Kapoor S, Misra A, Mathur A, Nusrat H, et al. Elevated levels of IL-8 in dengue hemorrhagic fever. J Med Virol. 1998;56:280-5.

61. Graham RR, Juffrie M, Tan R, Hayes CG, Laksono I, Ma'roef C, Erlin, Sutaryo, Porter KR, Halstead SB. A prospective seroepidemiologic study on dengue in children four to nine years of age in Yogyakarta, Indonesia I. studies in 1995-1996. Am J Trop Med Hyg. 1999;61:412-9.

62. Agarwal R, Kapoor S, Nagar R, Misra A, Tandon R, Mathur A, Misra AK, Srivastava KL, Chaturvedi UC. A clinical study of the patients with denque hemorrhagic fever during the epidemic of 1996 at Lucknow, India. Southeast Asian J Trop Med Public Health. 1999:30:735-40.

63. Moutailler S, Krida G, Schaffner F, Vazeille M, Failloux AB. Potential vectors of Rift Valley fever virus in the Mediterranean region. Vector Borne Zoonotic Dis. 2008;8:749-54.

64. Chaturvedi UC, Elbishbishi EA, Agarwal R, Raghupathy R, Nagar R, Tandon R, Pacsa AS, Younis Ol, Azizieh F. Sequential production of cytokines by dengue virus-infected human peripheral blood leukocyte cultures. J Med Virol. 1999:59:335-40.

65. Abubakar I, Gautret P, Brunette GW, Blumberg L, Johnson D, Poumerol G, Memish ZA, Barbeschi M, Khan AS. Global perspectives for prevention of infectious diseases associated with mass gatherings. Lancet Infect Dis. 2012; 12:66-74

66. Mustafa AS, Elbishbishi EA, Agarwal R, Chaturvedi UC. Elevated levels of interleukin-13 and IL-18 in patients with dengue hemorrhagic fever. FEMS Immunol Med Microbiol. 2001;30:229-33.

67. Barniol J, Gaczkowski R, Barbato EV, da Cunha RV, Salgado D, Martinez E, Segarra CS, Pleites Sandoval EB, Mishra A, Laksono IS, et al. Usefulness and applicability of the revised dengue case classification by disease: multicentre study in 18 countries. BMC Infect Dis. 2011;11:106.

68. Giraldo D, Sant'Anna C, Perisse AR, March Mde F, Souza AP, Mendes A, Bonfim M, Hofer CB. Characteristics of children hospitalized with dengue fever in an outbreak in Rio de Janeiro, Brazil. Trans R Soc Trop Med Hyg. 2011;105:601-3.

69. Rohani A, Aidil Azahary AR, Malinda M, Zurainee MN, Rozilawati H, Wan Najdah WM, Lee HL. Eco-virological survey of Aedes mosquito larvae in selected dengue outbreak areas in Malaysia. J Vector Borne Dis. 2014;51: 327-32.

70. Ahmed NH, Broor S. Dengue fever outbreak in Delhi, North India: a clinicoepidemiological study. Indian J Community Med. 2015;40:135-8.

71. Tuntaprasart W, Barbazan P, Nitatpattana N, Rongsriyam Y, Yoksan S, Gonzalez JP. Seroepidemiological survey among schoolchildren during the 2000-2001 dengue outbreak of Ratchaburi Province, Thailand. Southeast Asian J Trop Med Public Health. 2003;34:564-8.

72. Ooi EE, Wilder-Smith A, Ng LC, Gubler DJ. The 2007 dengue outbreak in Singapore. Epidemiol Infect. 2010;138:958-9. author reply 959-961.

73. Churrotin S, Kotaki T, Sucipto TH, Ahwanah NL, Deka PT, Mulyatno KC, Utami DA, Ranasasmita R, Soegijanto S, Kameoka M. Dengue virus type 1 strain isolated in Indonesia shows a close phylogenetic relationship with the strains that caused the autochthonous dengue outbreak in Japan in 2014. Jpn J Infect Dis. 2016. Article in Press.

74. Seed CR, Kiely P, Hyland CA, Keller AJ. The risk of dengue transmission by blood during a 2004 outbreak in Cairns, Australia. Transfusion. 2009;49: 1482-7.

75. Sweileh WM, Al-Jabi SW, Abuzanat A, Sawalha AF, AbuTaha AS, Ghanim MA Zyoud SH. Assessment of research productivity of Arab countries in the field of infectious diseases using Web of Science database. Infect Dis Poverty. 2015:4:2.

76. Sweileh WM, Al-Jabi SW, Sawalha AF, Zyoud SH. Bibliometric analysis of nutrition and dietetics research activity in Arab countries using ISI Web of Science database. Springerplus. 2014;3:718.

77. Sweileh WM, Al-Jabi SW, Shanti YI, Sawalha AF, Zyoud SH. Contribution of Arab researchers to ophthalmology: a bibliometric and comparative analysis. Springerplus. 2015;4:42. 
78. Sweileh WM, Zyoud SH, Al-Jabi SW, Sawalha AF. Quantity and quality of obesity-related research in Arab countries: assessment and comparative analysis. Health Res Policy Syst. 2014;12:33.

79. Sweileh WM, Zyoud SH, Al-Jabi SW, Sawalha AF. Assessing urology and nephrology research activity in Arab countries using ISI web of science bibliometric database. BMC Res Notes. 2014;7:258.

80. Sweileh WM, Zyoud SH, Al-Jabi SW, Sawalha AF. Contribution of Arab countries to breast cancer research: comparison with non-Arab Middle Eastern countries. BMC Womens Health. 2015;15:25.

81. Sweileh WM, Zyoud SH, Al-Jabi SW, Sawalha AF. Public, environmental, and occupational health research activity in Arab countries: bibliometric, citation, and collaboration analysis. Arch Public Health. 2015;73:1.

82. Sweileh WM, Zyoud SH, Al-Jabi SW, Sawalha AF. Bibliometric analysis of diabetes mellitus research output from Middle Eastern Arab countries during the period (1996-2012). Scientometrics. 2014:101:819-32.

83. Sweileh WM, Zyoud SH, Al-Jabi SW, Sawalha AF. Substance use disorders in Arab countries: research activity and bibliometric analysis. Subst Abuse Treat Prev Policy. 2014;9:33.

84. Gupta R, Tiwari R, Ammed KM. Dengue research in India: a scientometric analysis of publications, 2003-12. Int J Med Public Health. 2014;4:1-8.

85. Dutt B, Kumar S, Garg KC. Scientometric profile of global dengue research. Collnet J Scientometrics Inf Manage. 2010;4:81-91.

86. Mokdad AH, Jaber S, Aziz Ml, AlBuhairan F, AlGhaithi A, AlHamad NM, Al-Hooti SN, Al-Jasari A, AlMazroa MA, AlQasmi AM, et al. The state of health in the Arab world, 1990-2010: an analysis of the burden of diseases, injuries, and risk factors. Lancet. 2014:383:309-20.

87. Alwan A. Responding to priority health challenges in the Arab world. Lancet. 2014;383:284-6.

88. Bakkalbasi N, Bauer K, Glover J, Wang L. Three options for citation tracking: Google scholar Scopus and Web of science. Biomed Digit Libr. 2006;3:7.

\section{Submit your next manuscript to BioMed Central and we will help you at every step:}

- We accept pre-submission inquiries

- Our selector tool helps you to find the most relevant journal

- We provide round the clock customer support

- Convenient online submission

- Thorough peer review

- Inclusion in PubMed and all major indexing services

- Maximum visibility for your research

Submit your manuscript at www.biomedcentral.com/submit

C Biomed Central 